\title{
LONG-TERM FIRE HISTORY IN GREAT BASIN SAGEBRUSH RECONSTRUCTED FROM MACROSCOPIC CHARCOAL IN SPRING SEDIMENTS, NEWARK VALLEY, NEVADA
}

\author{
Scott Mensing ${ }^{1}$, Stephanie Livingston ${ }^{2}$, and Pat Barker ${ }^{3}$
}

\begin{abstract}
AвstRaCT.-We use macroscopic charcoal analysis to reconstruct fire history in sagebrush (Artemisia tridentata var. wyomingensis and A. tridentata var. tridentata), in Newark Valley, Nevada. We analyzed charcoal at continuous 1-cm intervals ( $\sim 7-127$ years), and pollen at 2 - to 10 -cm intervals $(\sim 70-263$ years) in a core spanning the last 5500 cal yr BP (calendar years before present). A charcoal peak in the historic period was associated with a >1400-ha fire dated to 1986 that burned in the watershed. We reconstructed the prehistoric fire history by inferring fires from similar charcoal peaks that were significantly greater than the background charcoal accumulation. Our results suggest the fire regime is climate and fuel driven. During periods of wetter climate, sagebrush increased and fires were more abundant, and during extended dry periods when sagebrush decreased, fires were less frequent. Our method does not allow calculation of a fire-return interval; however, our results support models that estimate a mean fire-return interval of up to a century in Artemisia tridentata var. wyomingensis. The charcoal record indicates that fires have increased within the historic period. This contrasts with pinyon/juniper studies that indicate an expansion of woodland associated with fewer fires in the historic period. We suggest that in the central Great Basin, a regime of frequent fires in sagebrush that limits woodland expansion is true for the sagebrush-woodland ecotone, but in sagebrush-dominated valleys with lower fuel loads, fires have always been less frequent. Protecting sagebrush-dominated valleys from frequent fire would appear to be consistent with the prehistoric fire regime.
\end{abstract}

Key words: sagebrush, fire history, charcoal, Nevada, Great Basin, Artemisia tridentata var. wyomingensis.

The invasion of cheatgrass (Bromus tectorum) throughout much of the Great Basin in the early 1900s (Mack 1981) has changed the fire regime within sagebrush- (Artemisia-) dominated landscapes, resulting in more frequent fires (Whisenant 1990). Total area burned per year has also increased; over the last 5 years, on average, $>275,000$ ha burned in Nevada each year (Western Great Basin Coordination Center 2004). Although it is evident that invasion of cheatgrass has increased the frequency and extent of fires in sagebrush environments, we still have a poor understanding of sagebrush fire history prior to 1900 A.D. Gruell (1985) reviewed journal accounts for references on fire made by early explorers and naturalists and concluded that fire was a major perturbation in the region before European settlement. However, such observations are widely scattered in time and space and provide no quantitative analysis of the frequency of fire in a specific vegetation cover.
Reconstructing fire history within sagebrush is problematic because fires are stand replacing. In contrast, in forested environments, evidence of past fires can be reconstructed from fire scars found on surviving trees. Tree-ring and fire-scar analysis allows us to identify and date prehistoric fire events. This method has been widely utilized throughout the West to reconstruct forest fire histories extending back hundreds of years (Swetnam 1993). In environments where fire-scarred trees grow within or directly adjacent to sagebrush, this technique has been used to infer sagebrush fire history (Houston 1973, Burkhardt and Tisdale 1976, Miller and Rose 1999). It is a question, however, whether fire-return intervals calculated through this method are representative of treeless valleys of the central Great Basin dominated by sagebrush, primarily Artemisia tridentata var. tridentata (Great Basin big sagebrush) and A. tridentata var. wyomingensis (Wyoming big sagebrush).

\footnotetext{
${ }^{1}$ Department of Geography, 201 Mackay Science, University of Nevada, Reno, NV 89557

23920 N.Westpoint Drive, Reno, NV 89509.

${ }^{3}$ State Archeologist, Bureau of Land Management, 1240 Financial Blvd., Reno, NV 89502.
} 
The purpose of this paper is to test the use of macroscopic charcoal recovered from sediments (Millspaugh and Whitlock 1995, Long et al. 1998, Whitlock and Anderson 2003) as a proxy for reconstructing fire history in sagebrush. Our goal is to provide the first quantitative charcoal analysis of fire history from a sagebrush-dominated valley in central Nevada. Charcoal analysis is one of the few methods available for reconstructing fire history within treeless landscapes. Mensing et al. (1999) used charcoal analysis to reconstruct fire history in shrub-dominated chaparral environments in California.

In central Nevada, pinyon-juniper woodlands containing Utah juniper (Juniperus osteosperma), western juniper (J. occidentalis), and single leaf pinyon (Pinus monophylla) typically occupy slopes above sagebrush-dominated valleys. Reconstructing fire histories in these woodlands is difficult because juniper are thin-barked and susceptible to fire for at least the first 50 years of growth (Miller and Rose 1999) and pinyons contain abundant resin and typically burn completely when exposed to flame (Robin Tausch personal communication). Further, relict stands of pinyon and juniper with scarred trees are typically confined to rocky ridges (Burkhardt and Tisdale 1976) and are not representative of soils that support sagebrush. The few published fire history studies of pinyon and juniper in east central Nevada (Blackburn and Tueller 1970, Gruell et al. 1994) and southwestern Utah (Tausch and West 1988) give no explicit estimates of prehistoric firereturn intervals in sagebrush-dominated environments (Fig. 1).

Our knowledge of sagebrush fire history comes almost entirely from fire-scar studies on ponderosa pine (Pinus ponderosa), western juniper, and Douglas-fir (Pseudotsuga mensezii), growing in association with $A$. tridentata var. vaseyana (mountain big sagebrush) from sites in Oregon (Gruell 1999, Miller and Rose 1999), Idaho (Burkhardt and Tisdale 1976), and Wyoming (Houston 1973), respectively (Fig 1). These studies suggest a fire-return interval of 15 to 25 years in A. tridentata var. vaseyana (Miller and Tausch 2001), but the study sites have more mesic climates than are found in central Nevada, and fuel loads are likely far greater. Annual precipitation at these sites ranged from $300 \mathrm{~mm}$ to $500 \mathrm{~mm}$ as compared with $185 \mathrm{~mm}$ at the central Nevada Field Lab near Austin, Nevada, or $240 \mathrm{~mm}$ in Ely, Nevada. We argue that a 15-25 year fire-return interval is not representative for sagebrush-dominated valleys in the central Great Basin where the primary species are A. tridentata var. tridentata and A. tridentata var. wyomingensis.

Miller and Rose (1999) were able to collect 12 fire-scarred western juniper stumps and logs in A. arbuscula (low sagebrush) in what they considered a fuel-limited environment in Oregon. They identified only 2 fires in the last 300 years with a period of 130 years between these events. This is the only published study that documents prehistoric fire history in sagebrush habitat that is not dominated by $A$. tridentata var. vaseyana.

Miller and Tausch (2001) presented a conceptual model of fire-return intervals in forested and sagebrush habitats dependent upon climate and fuel loads. For sagebrush, they suggested that as climate becomes more arid, fuel loads decrease and fire-return interval increases. The shortest fire-return interval (15-25 years) occurred in A. tridentata var. vaseyana, which also occupied the wettest habitat and had the highest fuel loads. Next in order they suggested A. tridentata var. wyomingensis at 50-100 years, A. arbuscula at 100-200 years, and then salt desert shrub (Atriplex spp.) at $>500$ years. This conceptual framework is supported by 7 published studies of $A$. tridentata var. vaseyana throughout the Intermountain West, and only 1 study of A. arbuscula (Miller and Tausch 2001). The fire-return intervals for A. tridentata var. wyomingensis and salt desert habitats are undocumented estimates. Wright and Bailey (1982) speculated that the natural fire return interval in sagebrush may be 100 years, but this argument was based simply on the time needed for sagebrush to succeed horsebrush (Tetradymia canescens) following fires in southeastern Idaho.

Sagebrush in valleys in the central Great Basin is dominated by A. tridentata var. wyomingensis and A. tridentata var. tridentata. Changes in fire regime in this habitat type due to invasion of cheatgrass are leading to conversion of sagebrush to annual grasses and demise of species dependent upon sagebrush. The increase of fine fuels in the interspaces between native shrubs has created a situation where some areas now burn every $3-5$ years (Whisenant 1990). The model presented by Miller and Tausch (2001) suggests that the prehistoric fire-return interval for A. tridentata 


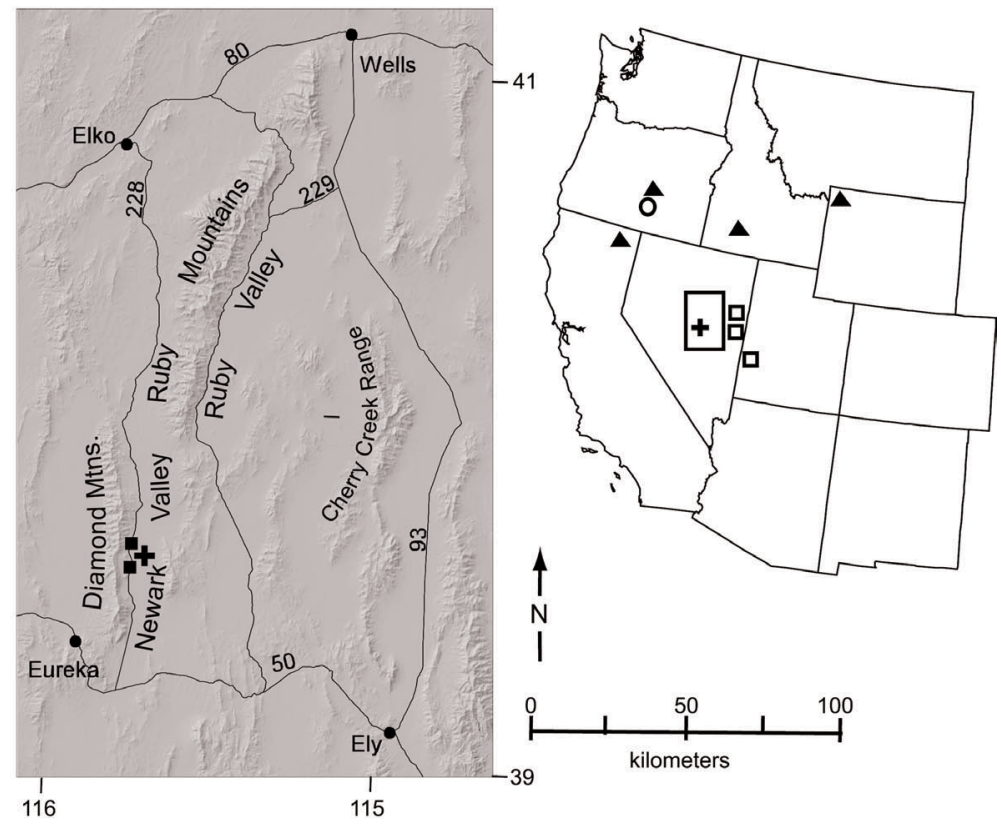

Fig. 1. Map of the study site and general location of fire studies referred to in the text. Symbols are as follows: cross $(+)$ core site; solid squares $(\boldsymbol{\square})$ recent fires $>400$ ha; triangles $(\mathbf{\Lambda})$ Artemisia tridentata var. vaseyana fire studies; open circle $(\bigcirc)$ A. tridentata var. arbuscula fire study; open squares $(\square)$ pinyon juniper fire studies that do not give an explicit fire-return interval for sagebrush. Numbers refer to highways.

var. wyomingensis may be approximately a century rather than 1 or 2 decades. It is critical to gain a better understanding of the prehistoric fire regime to support fire management policy. But, as described above, this will be difficult if not impossible using existing methods because of the problem finding trees with fire scars growing in these environments.

Unlike dendrochronologic studies that examine annual tree rings and are able to identify the exact year of a fire, charcoal studies utilize sediment cores extracted from lakes, bogs, or springs; except in cases of annually laminated sediments, each sample may represent several years to decades and specific fires cannot necessarily be resolved. Although this loss of temporal resolution means that we cannot reconstruct a specific fire-return interval, we are able to identify peaks in charcoal abundance that represent fire episodes when 1 or more fire events occur around the same time, and we can then relate this to changes in fire activity at the landscape level (Brunelle and Whitlock 2003). Charcoal in the upper sediments is typically compared with local fire history to calibrate charcoal accumulation rate and verify that peaks correspond with known fire events
(Millspaugh and Whitlock 1995). In the past century, invasion of cheatgrass has increased fire activity in the Great Basin. We can compare modern charcoal accumulation rates under the current fire regime with prehistoric accumulation rates before the invasion of cheatgrass as an estimate of the extent to which invasion of cheatgrass has altered the fire regime. We can also examine changes in fire activity in relation to climate change over long periods of time. This study attempts to characterize the fire regime in a sagebrush-dominated valley over the last 5500 years and compare this with the historic period, which has been influenced by increased human activity and invasion of annual grasses.

\section{Study Area And Methods \\ Site Selection and Core Recovery}

To reconstruct local fire history using charcoal analysis, the ideal coring site would be a small (<10 ha), deep (>10 m) lake with steep catchments and no stream input (Whitlock and Millspaugh 1996). In addition, an independent record of recent fire history from historic 
records or dendrochronological reconstructions would be preferred (Whitlock and Anderson 2003). Charcoal derived from known fires should be evident in the near surface sediments of the core to calibrate the charcoal record with the known fire history.

A challenge to such research in Nevada is the absence of small deep lakes; however, many valleys hold permanent springs fed by groundwater from adjacent mountain ranges. The unique snail fauna found in many Nevada springs (Taylor 1985) suggests that these springs have persisted continuously since the last glacial maximum, about 21,000 cal yr BP (calendar years before present), and are a potential source for long continuous sediment cores. We used a Geographic Information System (GIS) to identify lake and spring sites that had recent fires nearby in order to select a site with a known fire history to calibrate the charcoal signal. We compared a digital data layer of springs in Nevada with a Bureau of Land Management (BLM) digital map of fires from 1980 to 2000 to identify all fire events within $2 \mathrm{~km}$ of springs located in sagebrush cover types. Our analysis identified 2 fires that had occurred in 1986 (>1400 ha) and 1999 (>400 ha) and were located in close proximity to a spring complex in Newark Valley, central Nevada (Fig. 1).

We visited the site in October 2001 and were able to identify an old burned area $\sim 500 \mathrm{~m}$ from a large spring. A qualitative survey easily differentiated the burned and unburned areas. The burned area (judged from the regrowth to be from the 1986 fire) was dominated by widely spaced green rabbitbrush (Chrysothamnus viscidiflorus) and small sagebrush plants (A. tridentata var. wyomingensis; $<50 \mathrm{~cm}$ tall) with a thick growth of cheatgrass. In the unburned area sagebrush plants were $\geq 1 \mathrm{~m}$ tall and spaced more closely with only scattered rabbitbrush and little cheatgrass.

Our site, which we refer to as Newark Valley Pond (NVP; $\left.39^{\circ} 40^{\prime} \mathrm{N}, 115^{\circ} 44^{\prime} \mathrm{W}\right)$, is one of many springs in the valley (1750 m elevation). NVP is $\sim 7 \mathrm{~m}$ in diameter and flows through a wet meadow $\sim 30 \times 40 \mathrm{~m}$ to a pool $\sim 20 \mathrm{~m}$ in diameter with a maximum water depth of $50 \mathrm{~cm}$. The Diamond Mountains to the west of Newark Valley rise to $3216 \mathrm{~m}$ at Diamond Peak. The range is composed of Paleozoic sedimentary and metasedimentary rocks, including several limestone formations (Stewart and Carlson 1978).
The center of the pool had open water, surrounded by cattails (Typha spp.), and sedges (Carex spp) grew in shallow water. Moist ground contained rushes (Juncus spp.) and grasses (Distychlis spp.). Surrounding the pond were $A$. tridentata var. tridentata, A. tridentata var. wyomingensis, green rabbitbrush, greasewood (Sarcobatus vermiculatus), and shadscale (Atriplex confertifolia). Scattered Utah juniper grew on the rocky slopes above the site. Limber pine (Pinus flexilis) grew in the highest elevations above $\sim 3000 \mathrm{~m}$. Towards the playa in the center of the valley Bailey's greasewood (Sarcobatus baileyii) and shadscale increased in abundance.

We recovered 2 overlapping 3.3-m cores (NV01A and NV01B) using a 5-cm-diameter modified Livingstone corer. Core segments ranged in length from 10 to $60 \mathrm{~cm}$ and averaged $30 \mathrm{~cm}$. Cores were extruded into plastic tubes for transport and storage and refrigerated at $4^{\circ} \mathrm{C}$. A 5 -cm plastic tube was pushed into the upper sediments to recover the sediment-water interface with a minimum amount of disturbance. We used core NV01A for analysis and archived core NV01B.

The cores were split in the laboratory and the stratigraphy was described. Continuous $1-\mathrm{cm}^{3}$ subsamples were weighed, dried for 24 hours at $100^{\circ} \mathrm{C}$ to obtain percent water content, and finally burned in a furnace at $550^{\circ} \mathrm{C}$ to determine percent organic matter (Dean 1974). Other studies have found that fireinduced erosion sometimes leads to peaks in magnetic susceptibility associated with charcoal peaks (Long et al. 1998). We ran magnetic susceptibility analyses on our cores, but readings throughout the entire length were negligible.

\section{Charcoal Analysis}

Macroscopic charcoal $(>125 \mu \mathrm{m}$ and $>250$ $\mu \mathrm{m})$ was counted from continuous 1 -cm samples for the upper $1 \mathrm{~m}$ of core (Whitlock and Millspaugh 1996). Numerous studies have confirmed that charcoal fragments of $>125 \mu \mathrm{m}$ collect in depositional environments near burned areas and are representative of local fires (Whitlock and Anderson 2003).

Charcoal analysis followed the macroscopic sieving method described in Whitlock and Anderson (2003). We took 2.5- $\mathrm{cm}^{3}$ samples from continuous $1-\mathrm{cm}$ sections of the core. Sediments were disaggregated for 48 hours in sodium hexametaphosphate $(5 \%)$ and then 
washed with tap water through 63-, 125-, and $250-\mu \mathrm{m}$ sieves. Charcoal fragments were counted in water on grided rectangular petri dishes at 40X magnification using a stereomicroscope. Fragments in the $63-125 \mu \mathrm{m}$ fraction proved too small to make counting feasible, but every sample in the 125-250 $\mu \mathrm{m}$ and $>250 \mu \mathrm{m}$ fraction was counted. Charcoal fragments were identified by color (black to very dark brown) and structure (obvious cellular structure). All fragments were counted in each sample and samples were then archived in vials.

We calculated charcoal concentration (particles $\cdot \mathrm{cm}^{-3}$ ) from charcoal counts and divided by the number of years per centimeter in a sample to calculate charcoal accumulation rate (particles $\left.\cdot \mathrm{cm}^{-2} \mathrm{yr}^{-1}\right)$. Charcoal accumulation rate data were analyzed for peaks that may represent fires using the CHAPS charcoal analysis program (Long et al. 1998). The CHAPS program decomposes charcoal accumulation time series into 2 components: (1) "background" charcoal, a locally weighted average of charcoal produced as a result of fuel, climate, and transport processes, and (2) "peaks" that represent higher than average accumulation rates assumed to be associated with local fire episodes.

Charcoal accumulation rates were log transformed for analysis to enhance variability in the record. To calculate charcoal "background," accumulation rate data was resampled into 10yr intervals to produce a decadal time series. The time series was then fit to a temporal window that produced a running average that smoothed the data but still captured the variability. We fit 250-, 500-, and 750-year windows and selected the 500-year window as the best fit. "Peaks" were identified as points in time where charcoal accumulation exceeded the moving average. Values above 1.0 represent charcoal accumulation greater than the "background" value; the higher the value, the greater the positive deviation above the "background." We tested threshold values of 1.0, 1.1, and 1.2 to identify peaks that represent inferred fire episodes. The frequency of peaks per thousand years was calculated using the lowest threshold value (1.0).

\section{Pollen Analysis}

Twenty-two 1-cm-thick samples were taken for pollen analysis. Sample interval ranged from $2 \mathrm{~cm}$ to $10 \mathrm{~cm}$ apart and was determined from the age model so that average time between samples was 263 years. Pollen preparation followed standard methods (Faegri and Iversen 1985). A known quantity of Lycopodium spores was added to each sample to calculate pollen concentration (Stockmarr 1971). Pollen was identified to the lowest possible taxonomic level using modern reference material and published pollen keys, (Moore and Webb 1978, Kapp et al. 2000). TCT (Taxodiaceae/ Cupressaceae/Taxaceae) pollen was assumed to be Juniperus since no other member of these families occurs in the region. Algae (Pediastrum) was also identified (Jankovská and Komárek 1982).

A minimum of 200 pollen grains were counted in each sample. Higher counts (e.g., 400 grains per sample) are typically used when quantification and identification of rare pollen types is desired; however, our goal was simply to characterize changes in the major vegetation types. For this reason the lower count total was used to expedite sample processing. Pollen percentages were calculated from the sum of terrestrial pollen. Pollen accumulation rates were calculated by dividing pollen concentration by number of years represented by the sample. We calculated the ratio of Artemisia to Chenopodiaceae/Sarcobataceae pollen as a proxy for climate change, where increased Artemisia indicated a wetter climate and increased Chenopociaceae/Sarcobataceae indicated a drier climate (Mensing et al. 2004).

\section{Results}

Age Model and Sediment Analysis

We were unable to find seeds, twigs, or large enough quantities of charcoal to date directly using commercial AMS methods; therefore, radiocarbon dates were obtained on bulk organic sediment from 2-cm-thick core sections using AMS radiocarbon techniques (Table 1). The basal radiocarbon date for core NV01A was $22,120 \pm 90{ }^{14} \mathrm{C}$ (Beta 185018), indicating that the spring has persisted since the last glacial maximum. There were no discontinuities or sand layers that might indicate a cessation of flow or erosion event. Because this research represents a test of methodology, we 
TABLE 1. Radiocarbon dates and calibrated ages for core NV01A-01, Newark Valley, Nevada. All ${ }^{14}$ C ages are on bulk organic sediment. All ages were adjusted 640 years to account for old carbon. ${ }^{14} \mathrm{C}$ ages were calibrated using CALIB 4.4 and the INTCAL98 ${ }^{14} \mathrm{C}$ calibration data set (Stuiver and Reimer 1993, Stuiver et al. 1998). In cases of multiple intercepts, the 2 sigma values represent the age range with the highest probability distribution and the single cal $\mathrm{BP}$ age is the median value.

\begin{tabular}{|c|c|c|c|c|c|}
\hline Lab \# & Depth $(\mathrm{cm})$ & ${ }^{14} \mathrm{C}$ age & ${ }^{14} \mathrm{C}$ age adjusted & Cal BP age & 2 sigma \\
\hline Beta 183676 & 0 & $640 \pm 50$ & 0 & 0 & - \\
\hline Beta 183677 & 20 & $790 \pm 40$ & $150 \pm 40$ & 140 & $(1-280)$ \\
\hline Beta 185016 & 31 & $1290 \pm 40$ & $650 \pm 40$ & 580 & $(550-610)$ \\
\hline Beta 183678 & 42 & $1840 \pm 40$ & $1200 \pm 40$ & 1120 & $(1050-1190)$ \\
\hline Beta 185017 & 70 & $4810 \pm 40$ & $4170 \pm 40$ & 4690 & $(4610-4770)$ \\
\hline Beta 183679 & 100 & $5410 \pm 50$ & $4770 \pm 50$ & 5530 & $(5450-5600)$ \\
\hline Beta 185018 & 340 & $22,120 \pm 90$ & (not used in this study) & & \\
\hline
\end{tabular}

did not analyze the entire core, and we present results from only the upper meter of sediment (the last 5500 cal yr BP).

The presence of calcium carbonate nodules in the core suggested that the sediments were probably enriched with old carbon and could give old dates. Springs emerging from calcareous rocks such as those in the Diamond Range often carry dissolved "dead" carbon that is not in equilibrium with atmospheric carbon. Subaqueous organisms incorporate this old carbon in their structure. We obtained 1 date from the surface sediments $(0-2 \mathrm{~cm}$ depth) to test for old carbon reservoir effects. The surface sediments returned a date of $640 \pm 50 \mathrm{BP}$ (Beta-183676) suggesting a hard water effect in the organic sediments. We assume that the water source for the spring has not changed over time and that incorporation of old carbon by organisms in the spring has been constant over time. To account for the reservoir effect, 640 years were subtracted from all dates to get an adjusted radiocarbon age. All dates were then calibrated using CALIB 4.4 (Stuiver and Reimer 1993, Stuiver et al. 1998), and they are presented in calendar years before present (cal yr BP).

The age model (Fig. 2) indicated that the upper $20 \mathrm{~cm}$ of sediment represented the historic period $(0-150 \mathrm{cal}$ yr $\mathrm{BP})$ with a rapid sedimentation rate of $1 \mathrm{~cm}$ every 7 years $(0.133$ $\left.\mathrm{cm} \cdot \mathrm{yr}^{-1}\right)$. From 20-41 cm (150-1100 cal yr $\mathrm{BP})$, sedimentation slowed to $1 \mathrm{~cm}$ every 47 years $\left(0.021 \mathrm{~cm} \cdot \mathrm{yr}^{-1}\right)$. Sedimentation was slowest from $41-70 \mathrm{~cm}(1100-4700 \mathrm{cal} \mathrm{yr} \mathrm{BP})$ accumulating at a rate of $1 \mathrm{~cm}$ every 127 years $\left(0.008 \mathrm{~cm} \cdot \mathrm{yr}^{-1}\right)$. Sedimentation was fairly rapid from $70-100 \mathrm{~cm}(4700-5500 \mathrm{cal} \mathrm{yr} \mathrm{BP})$ at $1 \mathrm{~cm}$ every 28 years $\left(0.036 \mathrm{~cm} \cdot \mathrm{yr}^{-1}\right)$.
From the sediment-water interface down to $20 \mathrm{~cm}$, sediments were dark brown in color and high in organic matter (17\% organic) compared with the remainder of the core (Fig. 3). Between $20 \mathrm{~cm}$ and $50 \mathrm{~cm}$, sediments were clay with silt, color shifted from a dark gray to a medium light gray, and percent organics decreased from $17 \%$ to $5 \%$. Many fragments of unidentified snail shells were mixed throughout the sediments. Between $50 \mathrm{~cm}$ and $85 \mathrm{~cm}$ sediments became an inorganic (5\%) lightgray clay, and calcium carbonate nodules ranging from $0.25 \mathrm{~cm}^{3}$ to $1 \mathrm{~cm}^{3}$ were encountered at depths of 58-62 cm, 71-77 cm, and 80-82 $\mathrm{cm}$. Between $85 \mathrm{~cm}$ and $100 \mathrm{~cm}$ the color changed to dark gray green but the sediment remained inorganic clay.

\section{Charcoal Analysis}

There was an excellent correspondence between the 125- and $250-\mu \mathrm{m}$ fractions (Fig. 3) suggesting that both size fractions were likely recording local fires (i.e., from the adjacent hill slopes). All analyses used total charcoal. Charcoal accumulation rates were highest within the last 130 years with accumulations an order of magnitude greater than during the prehistoric period. Within the historic period, there was one distinct charcoal peak centered about $100 \mathrm{cal}$ yr BP (15 cm depth). The downcore sediments showed fluctuations in charcoal accumulation that are muted but still apparent, centered on $600,1000,2400$, and $5250 \mathrm{cal}$ yr BP.

The smoothed charcoal background level of the log-transformed data allowed identification of distinct charcoal peaks (Fig. 4). All 3 threshold values identified a series of closely 


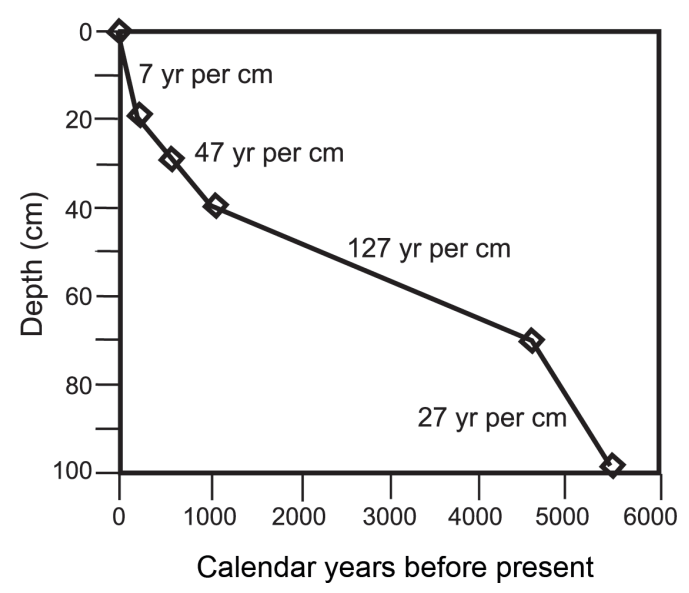

Fig. 2. Age model for core NV01A-01. Open diamonds $(\diamond)$ represent dated samples. Sedimentation rates between dated samples are shown.

spaced charcoal peaks (50-110 years apart) between 5500 and $4700 \mathrm{cal} \mathrm{yr} \mathrm{BP.} \mathrm{After} 4700 \mathrm{cal}$ yr BP the lowest threshold (1.0) continued to indicate regular charcoal peaks about every 350 years. The more conservative threshold (1.2) included long periods with no charcoal peaks, between 4700 and 3800, 3800 and 2900, and 2400 and 1100 cal yr BP. All thresholds indicated charcoal peaks centered on 1070, 960, 540 , and $100 \mathrm{cal} \mathrm{yr}$ BP. The inferred fire frequency ranged from about 10 fires per 1000 years between 5500 and $5000 \mathrm{cal}$ yr BP, to only 2 per 1000 years between 4000 and 1000 cal yr BP. In the last 1000 years there have been more fire episodes, but these are still widely spaced in time.

\section{Pollen Analysis}

Total pollen accumulation (Fig 5) was very low for much of the core (<500 grains $\cdot \mathrm{cm}^{-2}$ $\left.\mathrm{yr}^{-1}\right)$. Accumulation rates were highest at about $5000 \mathrm{cal}$ yr BP and within the last 500 years. The ponded water on the site today appears to be largely historical. Aquatic pollen types (Typha [cattails], Cyperaceae [sedges], Myriophyllum [water milfoil], and Potamogeton [pondweed]) were only abundant within the upper $20 \mathrm{~cm}$. The percentage of unknown pollen grains was also highest in the surface sediments, probably the result of exotic species invading the pond edge. Although the core had no indication of a break in sedimentation and prolonged desiccation, the presence of Cyperaceae pollen in nearly every sample indicated that for much of the site's history, it was a wet meadow. The high percentage of indeterminate pollen types (average 19\%) is evidence of poor preservation as compared to a lake environment. Typha was present 5200 cal yr BP, suggesting that the site must have had standing water at that time. Pollen accumulation rates were also higher at that time and pollen was better preserved.

Between 5500 and 4400 cal yr BP, the pollen record had high percentages of Artemisia (31\%-57\%) and Pinus (18\%-30\%) and low percentages of Chenopodiaceae and Sarcobataceae (2\%-9\%; hereafter referred to as Chenopodiaceae, the more common pollen type) and Juniperus (0\%-1\%; Fig. 5). Beginning about 4000 cal yr BP, Chenopodiaceae increased, averaging 19\% over the remainder of the core. Artemisia was generally less abundant over the last 4000 years, averaging $22 \%$. Artemisia increased in importance about 3000 and 800 cal yr BP. The A/C ratio provided a measure of the change in relative importance of Artemisia (sagebrush) and Chenopodiaceae (salt desert shrub) over time. Sagebrush grows on the slopes above the basin and requires more moisture than salt desert shrub, which dominates on the valley floor. The $\mathrm{A} / \mathrm{C}$ ratio indicated an abundance of sagebrush between 5500 and 4000 cal yr BP, with a shift of dominance to salt desert shrub about 3400 cal yr BP. Sagebrush again predominated between 3200 and 2500 cal yr BP. From 2500 to about 1000 cal yr BP, saltbush was generally abundant. Sagebrush increased again between 1000 and $400 \mathrm{cal} \mathrm{yr} \mathrm{BP,}$ and then salt desert shrub again dominated from $400 \mathrm{cal}$ yr BP to about the beginning of the historic period.

Juniperus is uncommon in the record until about $1400 \mathrm{cal}$ yr BP. It reached its maximum percentage $350 \mathrm{cal} \mathrm{yr} \mathrm{BP}$ and declined in the present period. Grasses (Poaceae) were generally abundant between about 3000 and 1000 cal yr BP, reaching a maximum of $17 \%$ about 2100 cal yr BP. Sunflower species (Asteraceae) varied little over the record.

\section{Discussion}

\section{Calibrating the Fire Record}

To correlate charcoal abundance with fire history, charcoal peaks in the upper sediments were compared with known local fires (Millspaugh and Whitlock 1995). The record clearly 


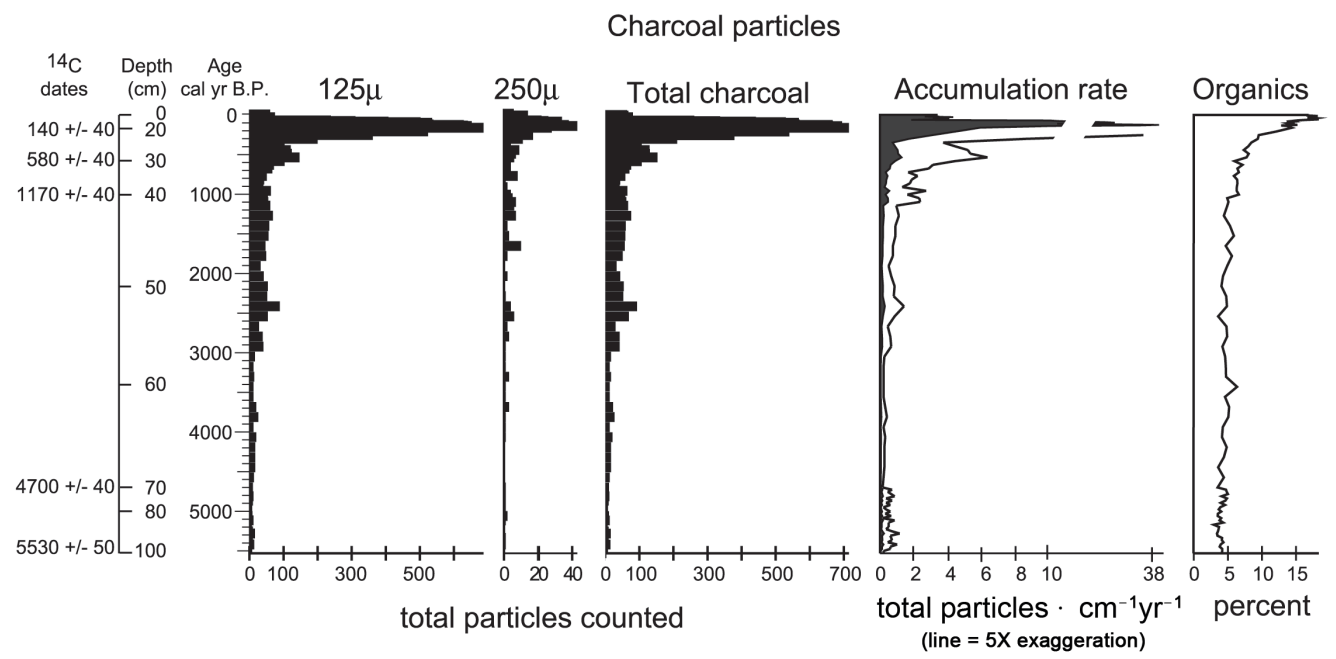

Fig. 3. Charcoal particles counted by size fraction $(125 \mu \mathrm{m}$ and $250 \mu \mathrm{m})$, total charcoal particles counted, charcoal accumulation rate for total charcoal, and percent organic matter of sediments. The unfilled line in the accumulation rate figure represents 5 times exaggeration.

demonstrated that the amount of charcoal produced in the historic period was significantly greater than in the prehistoric period, indicating that fires increased following settlement. In the historic period, charcoal reached its highest peak at $15 \mathrm{~cm}$ depth, dating to about 100 cal yr BP. Our knowledge of local fire history is not comprehensive enough to be able to correlate this peak with one specific event, but the abundance of charcoal in the surface sediments supports our hypothesis that charcoal peaks should be associated with known fire episodes and indicates that the charcoal record can be used as a proxy for local fire history.

The charcoal peak at $15 \mathrm{~cm}$ most likely represents the 1986 fire which burned >1400 ha within the local drainage. If our age model is correct, evidence for this fire should have appeared closer to the surface, about $5 \mathrm{~cm}$ depth. Given the difficulties of dating the historic period with radiocarbon techniques, there is some error in the exact depth to expect the 1986 event. However, there is ample evidence to establish that the upper $20 \mathrm{~cm}$ contains the historic period, including a sharp increase in sedimentation rate, an increase in percent organic matter, and the sudden appearance of plants that require standing water, probably associated with improvements to the spring designed to provide permanent water for livestock.
It is likely that charcoal has been mixed down core through bioturbation and trampling by cattle. The pond is clearly used by livestock for watering, and it is reasonable to expect that the upper sediments have been mixed downward. The high rates of charcoal deposition may also be a reflection of sediment focusing resulting from paths leading off hillslopes towards the water holes. There is also the possibility that some charcoal in the historic period is the result of fires set by early settlers. We have no direct evidence of fires from the late 1800s and early 1900s near the site. However, Eureka, located about $65 \mathrm{~km}$ to the south, was an active mining community, and it is possible that settlers in the Newark Valley set fires.

Although we cannot eliminate the possibility that the historic charcoal peak is the accumulation of more than 1 fire event, we have verified that the occurrence of a very large, known fire event is associated with a significant peak in charcoal. This evidence indicates that small spring-fed pools in low elevation valleys capture charcoal and can be used as a proxy for reconstructing fire history. The slow sedimentation rate in portions of our core restricts our interpretation to changes in fire activity on time scales of about 1 century. In this reconstruction, we do not identify a specific fire-return interval for sagebrush, since charcoal cannot be linked to an exact location; 


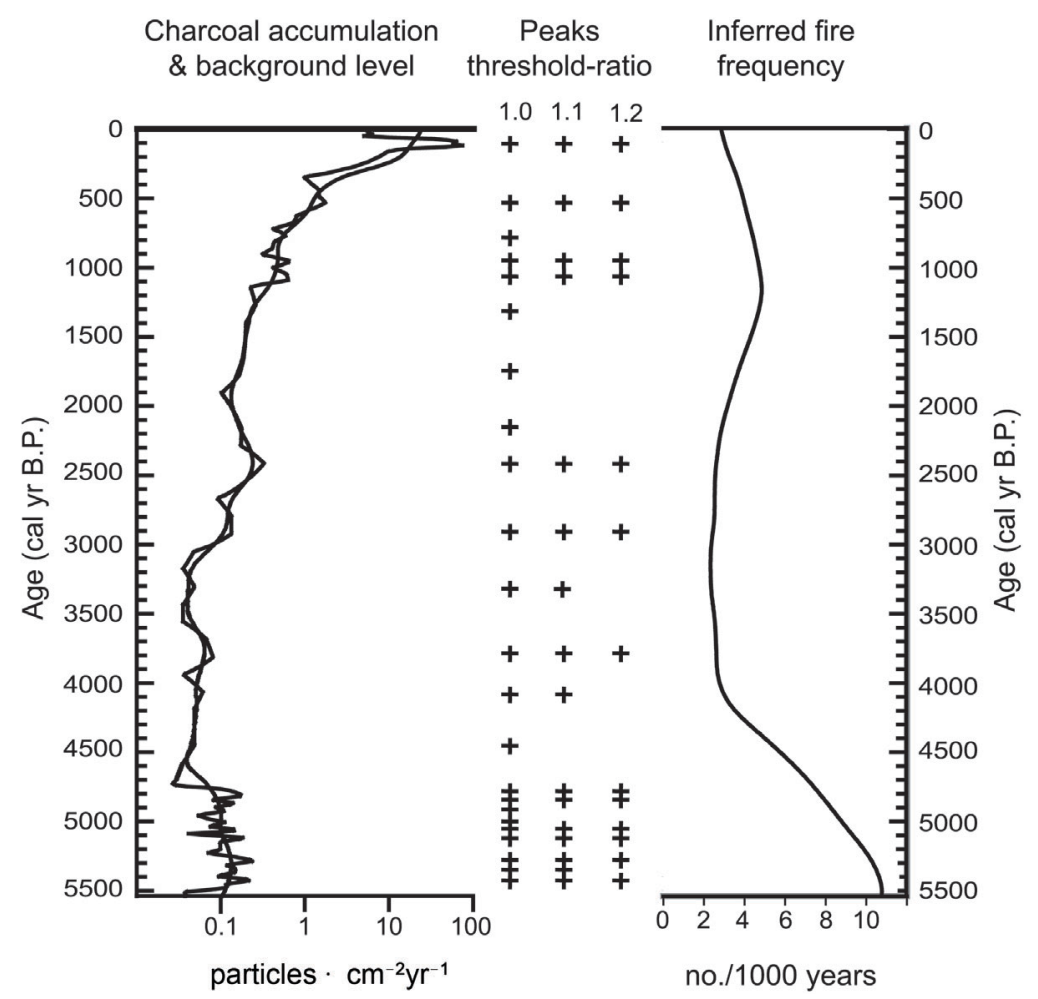

Fig. 4. Log-transformed charcoal accumulation rate plotted over a smoothed background level using a 500-year smoothing window. Crosses represent charcoal peaks at 3 different threshold levels indicating inferred fire events. Inferred fire frequency is calculated for the 1.0 threshold-ratio value.

however, we use the charcoal evidence to infer the occurrence of local fires or distinct periods in time when fire activity increased.

\section{Reconstruction of Fire, Vegetation, and Climate History}

Because this is the first attempt to use charcoal to reconstruct fire history in sagebrush, it is unclear which threshold value best characterizes past fire history. The peak in the historic period had the greatest deviation from the background level (Fig. 4) and was evident at each of the 3 threshold values. The 1.0 threshold value identified 23 inferred fire episodes in the prehistoric period. More restrictive criteria reduced the number of inferred episodes to 16 or 13 (1.1 and 1.2 threshold values, respectively). Comparison of the charcoal and pollen records suggests that number of fires is a function of amount of fuel available.

A fairly good correlation existed between abundance of sagebrush and number of fires (Fig. 6). The inferred fire frequency generally paralleled the $\mathrm{A} / \mathrm{C}$ ratio, with more fires occurring during periods when sagebrush was more abundant. Fire activity was greatest between 5500 and 4700 cal yr BP with 7-11 inferred fire episodes, or at least 1 about once per century. At that time, sagebrush was much more abundant on the landscape than today and salt desert shrub was nearly absent from the site. Evidence of Typha pollen (Fig. 5) indicates that the site held standing water, suggesting a wetter climate. Pinus pollen was at its highest levels at this time. A number of proxy records in the Great Basin indicated a wetter climate about 5000 cal yr BP. Archeological sites increased in abundance beginning about 5000 cal yr BP (Grayson 1993). At Ruby Marsh, just north of Newark Valley, about 5000 cal yr BP, there is evidence of deeper water and a decline in shadscale (Thompson 1992). The Great Salt Lake, Utah, was also fresher and deeper at that time (Madsen et al. 2001).

Beginning about $4700 \mathrm{cal} \mathrm{yr} \mathrm{BP}$ the number of fires decreased as salt desert shrub began to 


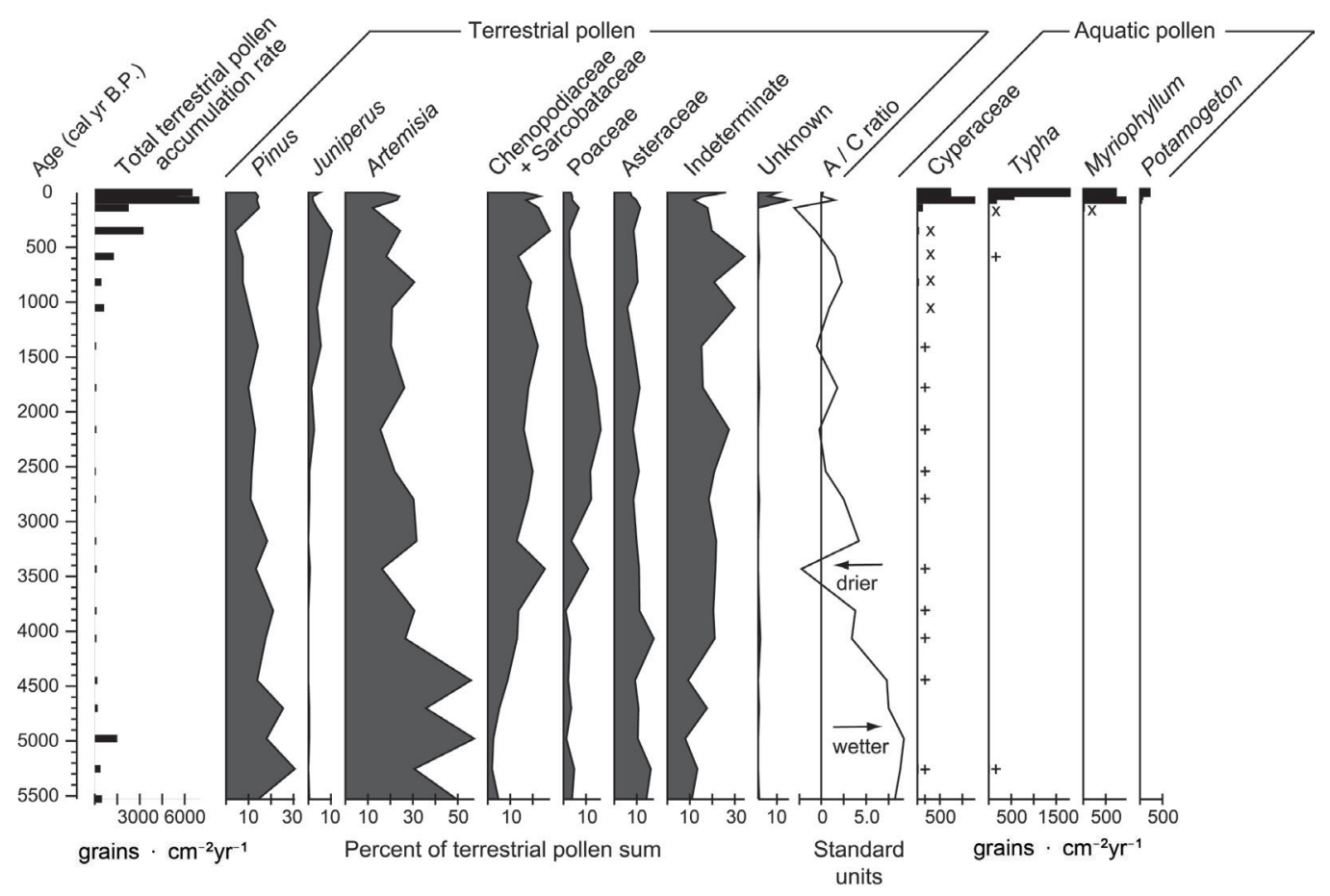

Fig. 5. Pollen diagram of the most common pollen types for Newark Valley Pond. Core chronology is in calendar years before present. The $\mathrm{A} / \mathrm{C}$ ratio (Artemisia / Chenopodiaceae + Sarcobataceae) is calculated as $(\mathrm{a}-\mathrm{c}) /(\mathrm{a}+\mathrm{c})$ where "a" represents percent Artemisia pollen and "c" represents percent Chenopodiaceae + Sarcobataceae pollen. Positive values represent increased Artemisia (wetter climate) and negative values represent increased Chenopodiaceae + Sarcobataceae (drier climate). Aquatic pollen are given as accumulation rate. An " $\mathrm{x}$ " indicates $>10$ and $<40 \mathrm{grains}^{\circ} \mathrm{cm}^{-2} \mathrm{yr}-1$ and a cross $(+)$ indicates $<10$ grains $\cdot \mathrm{cm}^{-2} \mathrm{yr}^{-1}$.

steadily increase in comparison with sagebrush. The pollen record indicated a general drying trend, with a dominance of salt desert shrub and a minimum of sagebrush culminating about $3400 \mathrm{cal} \mathrm{yr} \mathrm{BP}$. This corresponded with a decrease in the number of inferred fire episodes. The abrupt change in fire frequency at that time may be partially an artifact of the age model and the abrupt change in sedimentation rate (Fig. 2). A higher-resolution age model would probably show a smoother transition at this point.

By 3200 cal yr BP, sagebrush was increasing in abundance and continued until about 2500 cal yr BP, although percent Artemisia pollen was still well below values observed from 4500 to 5500 cal yr BP (Figs. 4, 6) The timing of the increase corresponds with the Neoglacial period (3500 to 2600 cal yr BP) defined by Tausch et al. (2004) as dominated by cool and wet climate. Sagebrush increased within the Great Basin at this time and salt desert shrub decreased (Wigand and Rhode
2002). Two fire episodes were identified during this period, one at $2900 \mathrm{cal} \mathrm{yr} \mathrm{BP}$ and the other near the end of the period at $2450 \mathrm{cal} \mathrm{yr}$ BP. We expected a higher fire episode frequency during this period.

Between 2450 and 1100 cal yr BP there were no charcoal peaks that were greater than the 1.0-threshold level and we infer a minimum amount of fire activity (Figs. 4, 6). The period between 2600 and 1600 cal yr BP has been recognized as a period of extended drought in the Great Basin (Tausch et al. 2004). The A/C ratio is low throughout most of this period, supporting the interpretation of an extended drought. Grass became important during this period (Fig. 5). In wet meadow environments, grasses replace sedges as the water table drops, resulting in a dry meadow. A pollen core from Kingston Meadow, in the Toiyabe Range about $100 \mathrm{~km}$ to the west indicated that that wet meadow was converted to a grassy flat about 2100 cal yr BP (Tausch et al. 2004). Plant macrofossils found in woodrat middens adjacent to 

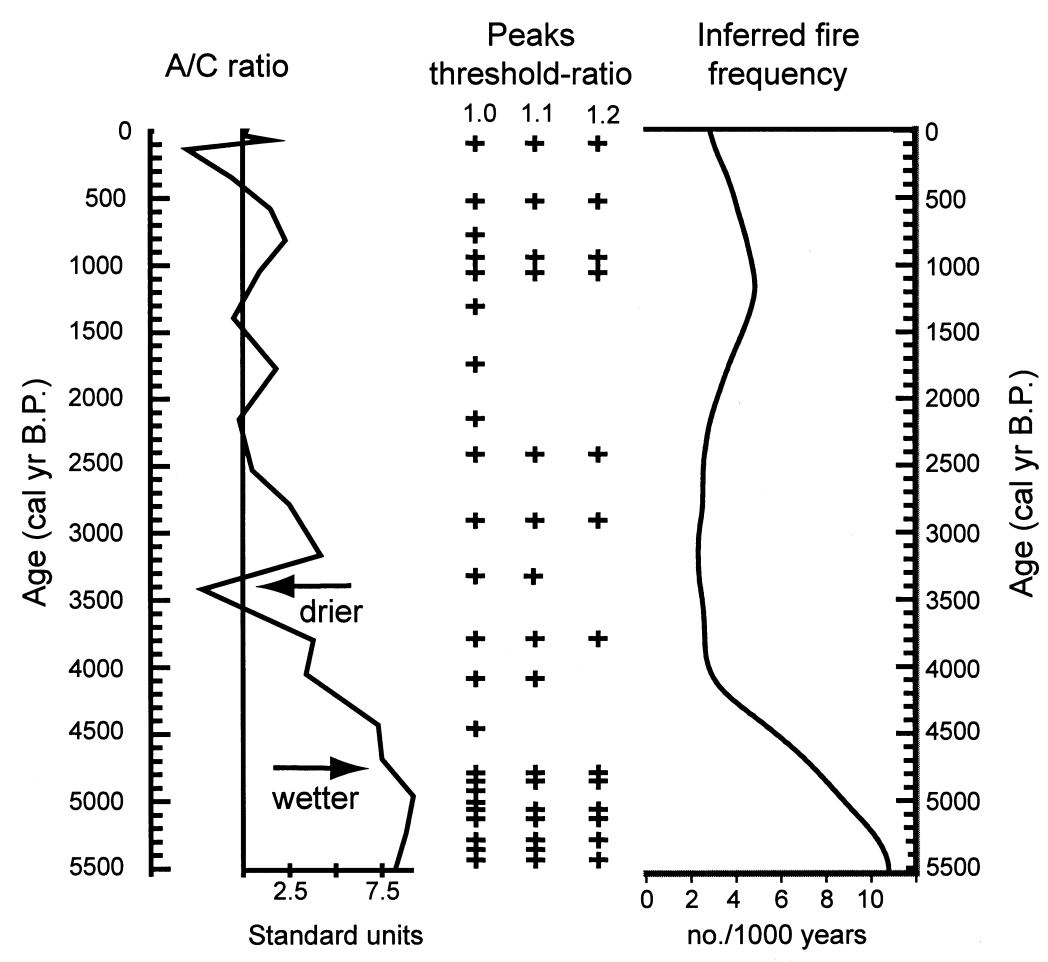

Fig. 6. The A/C ratio plotted with inferred fires. Crosses represent charcoal peaks at 3 different threshold levels indicating inferred fire events. Inferred fire frequency is calculated for the 1.0 threshold-ratio value. The $\mathrm{A} / \mathrm{C}$ ratio (Artemisia / Chenopodiaceae + Sarcobataceae) is calculated as $(\mathrm{a}-\mathrm{c}) /(\mathrm{a}+\mathrm{c})$ where "a" represents percent Artemisia pollen and "c" represents percent Chenopodiaceae + Sarcobataceae pollen. Positive values represent increased Artemisia (wetter climate) and negative values represent increased Chenopodiaceae + Sarcobataceae (drier climate).

riparian zones within the Toiyabe Range showed a decrease in species diversity during this time period. Elsewhere in the Great Basin, chenopods and greasewood expanded (Wigand 1987, Wigand and Rhode 2002). Expansion of grass may also have occurred due to increased summer monsoonal precipitation (Wigand 1987). Summer rainfall does not favor shrubs, however, and would not have promoted shrub density. During this period it appears that salt desert shrub expanded in Newark Valley, total fuel decreased, and fires were probably rare.

Sagebrush again increased between 1100 and $600 \mathrm{cal}$ yr BP and fire activity increased as well. Higher resolution records from across the Great Basin identified great variability during that time, with century-long droughts interspersed with wet periods (Tausch et al. 2004, Mensing et al. 2004). The resolution of the NVP pollen record was insufficient to capture this variability, but both the pollen and charcoal records indicated an increase in fuel and fires when compared with the previous period.

\section{Sagebrush Fire Patterns}

Our study is the first attempt to reconstruct the long-term fire history in Great Basin sagebrush using charcoal analysis, and therefore the conclusions are preliminary. Nevertheless, intriguing patterns have emerged.

Our data suggest that within Great Basin sagebrush, fires are climate and fuel driven. During wetter periods, sagebrush increases in abundance and density, thereby increasing the fuel load and decreasing plant interspaces. Fire is more likely to carry under such conditions and the period between fires becomes shorter. This conclusion supports the conceptual Great Basin fire model proposed by Miller and Tausch (2001) that described a longer firereturn interval as climate became drier and fuel loads decreased.

Although we were unable to calculate firereturn intervals using charcoal, the data support the Miller and Tausch (2001) model that suggests fire-return intervals may be as long as 
a century for Artemisia tridentata var. wyomingensis, not decades as has been documented for Artemisia tridentata var. vaseyana. Charcoal peaks were consistently separated by periods of 100 to 200 years or longer. During periods of drought, when salt desert shrub dominated, the time between fires lengthened. Miller and Tausch (2001) proposed a fire-return interval of $>500$ years in salt desert habitat, and our results support that estimate. Our results also indicate that in dense stands, created during periods of wetter climate or on wetter sites, the time between charcoal peaks shortened to 50-100 years, suggesting that fires will burn more frequently as the landscape changes in response to climatic change. One study of sagebrush recovery following prescribed burns in southwestern Montana found that on at least 1 site A. tridentata var. wyomingensis had not returned to preburn canopy cover 32 years after the fire (Wambolt et al. 2001).

We also found that the total quantity of charcoal produced during the historic period was an order of magnitude greater than at any time during the prehistoric period. The increase in charcoal in historic times indicates an increase in fire activity, quite likely associated with the invasion of cheatgrass, but also probably due to an increase in ignitions associated with settlement. This result contrasts with studies done in pinyon-juniper woodland that note a clear absence of fire during the last century associated with fire suppression, logging, and grazing (Blackburn and Tueller 1970, Tausch and West 1988, Gruell et al. 1994, Miller and Rose 1999).

In the Great Basin, pinyon-juniper woodland density is increasing, and trees are invading sagebrush along woodland-sagebrush ecotones. Because junipers are most susceptible to fire within their first 50 years of growth (Miller and Rose 1999), fires on these sites must have burned at frequencies of $<50$ years. But a long-term observational study of A. tridentata in southwestern Montana in a sagebrush/grassland habitat concluded that in the absence of disturbance such as fire, sagebrush will maintain itself indefinitely (Lommasson 1948). In a 61-year-old stand, A. tridentata seedlings established in the interspaces between mature shrubs, and there was no evidence of invasion of woodland in the absence of fire.
Where soil and climate are suitable for pinyon and juniper, woodlands can expand in the absence of fire. However, sagebrush fire frequencies inferred from such mesic sites may not be representative of sagebrush fire frequencies on xeric sites. Pollen evidence from this study (Fig. 5) and the Ruby Valley (Thompson 1992) support the interpretation that during the last 10,000 years woodlands have not invaded valley floors, which have remained dominated by sagebrush and salt desert vegetation. We suggest that in the central Great Basin, a regime of frequent fires in sagebrush that limits woodland expansion is restricted to the sagebrush-woodland ecotone, and that on valley bottoms with low fuel loads where sagebrush dominates, fires have always been less frequent. Prior to the historic period, charcoal production in these environments was very low and fires appear to have been uncommon. Protecting sagebrush-dominated valleys from frequent fire would appear to be consistent with the prehistoric fire regime.

Finally, this method warrants further testing. We plan to identify sites with faster sedimentation rates to increase our temporal resolution. We also hope to recover cores from sites in the southern central Great Basin where cheatgrass invasion is limited (Peterson 2003) and historic fire history may be different. The Free Air Carbon Dioxide Enrichment (FACE) studies being conducted on the Nevada Test Site have demonstrated that with increased global $\mathrm{CO}_{2}$, red brome (B. madritensis) and cheatgrass (B. tectorum) gain a competitive advantage and become more invasive (Smith et al. 2000). Preventing these species from invading sagebrush habitats where they do not currently dominate will be important for keeping fire out of these environments. A policy of fire suppression in sagebrush-dominated valleys may be appropriate given the long-term fire history and the relationship between cheatgrass expansion and fire activity. Maintaining sagebrush environments also has implications for the preservation of habitat utilized by endangered species in the Great Basin such as the Greater Sage-Grouse (Centrocercus urophasianus) and pygmy rabbit (Brachylagus idahoensis).

\section{ACKNOWLEDGMENTS}

We are thankful to Cathy Whitlock for providing a copy of the CHAPS software developed 
by the Environmental Change Research Group at the Department of Geography, University of Oregon, and to Jenn Marlon for helpful advice on running the program. We also appreciate the assistance of Paul Schlobom of the BLM who helped recover the core and Bryon Majusiak, Hannah Mensing, and Alex Mensing for assistance in processing and counting charcoal. This manuscript was improved through conversations with Robin Tausch and helpful reviews from Richard Periman and an anonymous reviewer. This research was funded by Assistance Agreements FAA020040 and FAA010017 from the BLM Joint Fire Sciences Program.

\section{Literature Cited}

Blackburn, W.H., and P.T. Tueller. 1970. Pinyon and juniper invasion in black sagebrush communities in east-central Nevada. Ecology 51:841-848.

Brunelle A., And C. Whitlock. 2003. Postglacial fire, vegetation and climate history in the Clearwater Range, Northern Idaho, USA. Quaternary Research 60:307-318.

Burkhardt, J.W., and E.W. Tisdale. 1976. Causes of juniper invasion in southwestern Idaho. Ecology 57 : $472-484$.

DEAn, W.E., JR. 1974. Determination of carbonate and organic matter in calcareous sediments and sedimentary rocks by loss on ignition: comparison to other methods. Journal of Sedimentary Research 44:242-248.

FAEgri, K., AND J. Iversen. 1985. Textbook of Pollen Analysis. 4th edition. Hafner Press, New York.

GraYson, D.K. 1993. The desert's past: a natural prehistory of the Great Basin. Smithsonian Institution Press, Washington, DC.

Gruell, G.E. 1985. Fire on the early landscape: an annotated record of wildland fires 1776-1900. Northwest Science 59:97-106.

1999. Historical and modern roles of fire in pinyonjuniper. Pages 24-28 in S.B. Monsen and R. Stevens, compilers, Proceedings: ecology and management of pinyon-juniper communities within the Interior West. RMRS-P-9, USDA, Forest Service, RMRS, Ogden, UT.

Gruell, G.E., L.E. Eddleman, and R. Jandl. 1994. Fire history of the pinyon-juniper woodlands of Great Basin National Park. Technical Report NPS/PNROSU/ NRTR-94/01, U.S. Department of the Interior, NPS, PNW Region, Seattle, WA.

Houston, D.B. 1973. Wildfires in northern Yellowstone National Park. Ecology 54:1111-1117.

Jankovská, V., AND J. KomáRek. 1982. Das Vorkommen einiger Chlorokokkalalgen in bohmischen Spatglazial und Postglazial. Folia Geobotanica et Phytotaxonomica, Praha 17:165-195.

Kapp, R.O., O.K. Davis, and J.E. King. 2000. Ronald O. Kapp's pollen and spores. 2nd edition. American Association of Stratigraphic Palynologists, College Station, TX.

Lommasson, T. 1948. Succession in sagebrush. Journal of Range Management 1:19-21.
Long, C.J., C. Whitlock, P.J. Bartlein, and S.H. MillsPAUGH. 1998. A 9000-year fire history from the Oregon Coast Range, based on a high-resolution charcoal study. Canadian Journal of Forest Research 28:774-787.

MACK, R.N. 1981. Invasion of Bromus tectorum L. into western North America: an ecological chronicle. Agro-Ecosystems 7:145-165.

Madsen, D., D. Rhode, D.K. Grayson, J.M. Broughton, S.D. Livingston, J. Hunt, J. Quade, et aL. 2001. Late Quaternary environmental change in the Bonneville Basin western USA. Palaeogeography, Palaeoclimatology, Palaeoecology 167:243-271.

Mensing, S.A., L.V. Benson, M. Kashgarian, and S. Lund. 2004. A Holocene pollen record of persistent droughts from Pyramid Lake, Nevada, USA. Quaternary Research 62:29-38.

Mensing, S.A., J. Michaelsen, and R. Byrne. 1999. A 560-year record of Santa Ana fires reconstructed from charcoal deposited in the Santa Barbara Basin, California. Quaternary Research 51:295-305.

Miller, R.F., and R.J. Tausch. 2001. The role of fire in juniper and pinyon woodlands: a descriptive analysis. Pages 15-30 in K.E.M. Galley and T.P. Wilson, editors, Proceedings of the Invasive Species Workshop: the role of fire in the control and spread of invasive species. Fire conference 2000: the first national congress on fire ecology, prevention, and management. Miscellaneous Publication No. 11, Tall Timbers Research Station, Tallahassee, FL.

Miller, R.F., AND J.A. Rose. 1999. Fire history and western juniper encroachment in sagebrush steppe. Journal of Range Management 52:550-559.

Millspaugh, S.H., AND C. Whitlock. 1995. A 750-year fire history based on lake sediment records in central Yellowstone National Park, USA. Holocene 5: 283-292.

Moore, P.D., AND J.A. WEBB. 1978. An illustrated guide to pollen analysis. Wiley and Sons, New York. 133 pp.

Peterson, E.B. 2003. Mapping percent-cover of the invasive species Bromus tectorum (cheatgrass) over a large portion of Nevada from satellite imagery. Report for the U.S. Fish and Wildlife Service, Nevada State Office, Reno, by the Nevada Natural Heritage Program, Carson City. 14 pp.

Smith, S.D., T.E. Huxman, S.F. Zitzer, T.N. Charlet, D. Housman, and J.S. Coleman. 2000. Elevated $\mathrm{CO}_{2}$ increases productivity and invasive species success in an arid ecosystem. Nature 408:79-82.

Stewart, J.H., and J.E. Carlson. 1978. Geologic map of Nevada, 1:500,000. U.S. Geological Survey and Nevada Bureau of Mines and Geology.

StockmarR, J. 1971. Tablets with spores used in absolute pollen analysis. Pollen et Spores 13:615-621.

Stuiver, M., And P.J. Reimer. 1993. Extended ${ }^{14} \mathrm{C}$ databases and revised CALIB radiocarbon calibration program. Radiocarbon 28:1022-1030.

Stuiver, M., P.J. Reimer, E. Bard, J.W. Beck, G.S. Burr, K.A. Hughen, B. Kromer, eT aL. 1998. INTCAL98 radiocarbon age calibration, 24,000-0 cal BP Radiocarbon 40:1041-1083.

Swetnam, T.W. 1993. Fire history and climate change in giant sequoia groves. Science 262:885-889.

Tausch, R., C. Nowak, and S. Mensing. 2004. Climate change and associated vegetation dynamics during the Holocene: the paleoecological record. Pages 24-48 in J.C. Chambers and J.R Miller, editors, Great Basin 
riparian ecosystems: ecology, management and restoration. Island Press, Covelo, CA.

Tausch, R.J., AND N.E. West. 1988. Differential establishment of pinyon and juniper following fire. American Midland Naturalist 119:174-184.

TAYLOR, D.W. 1985. Evolution of freshwater drainages and mollusks in western North America. Pages 265-321 in C.J. Smiley and A.J. Leviton, editors, Late Cenozoic history of the Pacific Northwest. American Association for the Advancement of Science, San Francisco, CA.

Thompson, R.S. 1992 Late Quaternary environments in Ruby Valley, Nevada. Quaternary Research 37:1-15.

Wambolt, C. L., K.S. Walhaouf, and M.R. Frisina. 2001. Recovery of big sagebrush communities after burning in south-western Montana. Journal of Environmental Management 61:243-252.

Western Great Basin Coordination Center. 2004. Bureau of Land Management: Nevada. Available from: www.nv.blm.gov/wgbcc/

WhisEnant, S.G. 1990. Changing fire frequencies of Idaho's Snake River Plains: ecological and management implications. Pages 4-10 in E.D. MacArthur, E.M. Romney, D. Stanley, and P.T. Tueller, compilers, Proceedings of the symposium on cheatgrass invasion, shrub die-off, and other aspects of shrub biology and management. General Technical Report INT-276.
Whitlock, C., And R.S. Anderson. 2003. Fire history reconstructions based on sediment records from lakes and wetlands. Pages 3-31 in T.T. Veblen, W.L. Baker, G. Montenegro, and T.W. Swetnam, editors, Fire and climatic change in the Americas. Ecological Studies, vol. 160. Springer-Verlag, New York.

Whitlock, C., And S.H. Millspaugh. 1996. Testing the assumptions of fire-history studies: an examination of modern charcoal accumulation in Yellowstone National Park, USA. Holocene 6:7-15.

Wigand, P.E. 1987. Diamond Pond, Harney County, Oregon: vegetation history and water table in the eastern Oregon desert. Great Basin Naturalist 47:427-458.

Wigand, P.E., AND D. RHODE. 2002. Great Basin vegetation history and aquatic systems: the last 150,000 years. Pages 309-368 in R. Hershler, D.B. Madsen, and D.R. Currey, editors, Great Basin aquatic systems history. Smithsonian Contributions to the Earth Sciences, No. 33, Smithsonian Institution Press, Washington, DC.

Wright, H.A., AND A.W. BAILEy. 1982. Fire Ecology: United States and southern Canada. Wiley and Sons, New York.

Received 2 August 2004 Accepted 4 February 2005 